\title{
MODEL SAINS TEKNOLOGI MASYARAKAT BERBASIS TRI HITA KARANA TERHADAP KOMPETENSI PENGETAHUAN IPA
}

\author{
I Nyoman Angga Suryawan ${ }^{1}$, Ida Bagus Surya Manuaba 2, Gusti Ngurah Sastra Agustika ${ }^{3}$ \\ 123 Program Studi Pendidikan Guru Sekolah Dasar, Universitas Pendidikan Ganesha, Bali, Indonesia \\ E-mail: nyoman.angga.suryawan@undiksha.ac.id
}

\begin{abstract}
Abstrak
Penelitian ini bertujuan untuk menganalisis dampak dari model pembelajaran Sains Teknologi Masyarakat berbasis Tri Hita Karana terhadap kompetensi pengetahuan IPA siswa kelas IV. Penelitian ini merupakan jenis penelitian quasi eksperimen dan menggunakan desain penelitian Non-equivalent Control Group Design. Populasi dari penelitian ini adalah seluruh siswa kelas IV SD dengan jumlah populasi 335 orang siswa. Sampel dalam penelitian ini berjumlah 71 orang siswa yaitu 34 orang siswa kelas IVB dari SDN 13 Sesetan yang menjadi kelompok eksperimen dan 37 orang siswa kelas IVB dari SDN 6 Sesetan yang menjadi kelompok kontrol. Pemilihan sampel dalam penelitian ini menggunakan teknik cluster random sampling. Data kompetensi pengetahuan IPA siswa dikumpulkan menggunakan tes dan pilihan ganda biasa sebagai instrumen. Uji-T digunakan untuk mendapatkan data pengetahuan siswa dalam muatan materi IPA. Hasil analisis data menunjukkan bahwa nilai rata-rata kelompok eksperimen lebih tinggi daripada nilai rata-rata kelompok kontrol $(61,74>57,43)$. Berdasarkan hasil analisis uji-t dengan derajat kebebasan ( $\mathrm{dk}=34+37-2=69$ ) dan pada taraf signifikansi $5 \%$ diperoleh $t$ hitung > t tabel $(2,391>1,994)$ maka H0 ditolak dan Ha diterima. Dengan demikian dapat disimpulkan, bahwa terdapat perbedaan yang signifikan kompetensi pengetahuan IPA siswa yang dibelajarkan melalui model pembelajaran Sains Teknologi Masyarakat berbasis Tri Hita Karana dan siswa yang dibelajarkan melalui pembelajaran konvensional. Ini berarti model pembelajaran Sains Teknologi Masyarakat berbasis Tri Hita Karana berpengaruh terhadap kompetensi pengetahuan IPA siswa kelas IV SD.
\end{abstract}

Kata Kunci: Sains Teknologi Masyarakat; Tri Hita Karana; Kompetensi Pengetahuan IPA

\begin{abstract}
This study aims to determine the effect of the Tri Hita Karana-based Science Technology Society learning model on the science competence of students in class IV. This research is a quasi-experimental study and uses a Nonequivalent Control Group Design research design. The population of this study were all fourth grade students with a total population of 335 students. The sample in this study amounted to 71 students, 34 students from IVB grade from SDN 13 Sesetan who became the experimental group and 37 students from IVB grade from SDN 6 Sesetan who became the control group. The sample selection in this study used a cluster random sampling technique. The science competency data of students was collected using a test method which was then analyzed using t-test. The results of data analysis showed that the average value of the experimental group was higher than the average value of the control group (61.74>57.43). Based on the results of the t-test analysis with degrees of freedom $(\mathrm{dk}=34+$ $37-2=69)$ and at a significance level of $5 \%$ obtained $t$ count $>t$ table $(2.339>1.994)$ then $\mathrm{H} 0$ is rejected and Ha is accepted. It can be concluded, then, that there are significant differences in the competencies of science students' knowledge which are learned through the Tri Hita Karana based Science Technology Society learning model and students who are taught through conventional learning. This means that the Tri Hita Karana-based Science Technology Society learning model has an effect on the science competence of the fourthgrade students of SD Gugus Jendral Sudirman in the South Denpasar District in 2019/2020 Academic Year.
\end{abstract}

Keywords: Science Technology Society; Tri Hita Karana; Science Knowledge

\section{PENDAHULUAN}

Pada hakikatnya manusia merupakan makhluk sosial yang tidak dapat hidup sendirian dan saling membutuhkan. Oleh karena itu, manusia membutuhkan suatu wadah yang dapat mengubah dan mengembangkan potensinya yaitu dapat diperoleh melalui pendidikan. Seseorang dapat mengubah dirinya menjadi lebih baik serta mengembangkan potensi yang ia miliki dengan suatu usaha yang disebut sebagai pendidikan (Sujana, 2014). Suatu kebutuhan yang penting bagi kehidupan manusia untuk mengubah seseorang menjadi yang lebih baik serta mengembangkan potensi yang dimiliki seseorang guna memberikan manfaat bagi kehidupan pribadinya maupun orang lain dapat diartikan sebagai pendidikan. Pendidikan juga dapat dikatakan sebagai kegiatan dalam rangka mempengaruhi peserta didik agar menjadi sebaik mungkin bagi lingkungannya(Riastuti, 2015). Tantangan peserta 
didik adalah lingkungannya sendiri, sehingga perlunya pembinaan agar peserta didik menjadi lebih tanggap dalam menghadapi suatu masalah(Hasjunianti, 2006).

Salah satu jenjang pendidikan yang memiliki peranan penting untuk dapat melanjutkan ke jenjang yang lebih tinggi adalah pendidikan dasar. Ini menjadikan pendidikan dasar sebagai acuan sebelum melangkah ke jenjang pendidikan selanjutnya. Jika pada tingkat pendidikan dasar kurang diperhatikan, kemungkinan kualitas pendidikan menjadi kurang baik. Ada 2 fungsi utama pendidikan dasar yaitu : 1 . Sebagai bekal kemampuan berfikir kritis dan penguasaan keterampilan dalam berbahasa Indonesia, dan 2. Sebagai dasar keberhasilan untuk dapat melanjutkan ke jenjang berikutnya.

Dalam dunia pendidikan tentunya terdapat kemampuan dalam menguasai atau melaksanakan suatu bidang tertentu, kemampuan tersebut disebut juga sebagai kompetensi. Kompetensi merupakan tindakan cerdas, dan penuh tanggung jawab seseorang dalam melaksanakan tugas-tugas di bidang pekerjaan tertentu. Jompetensi juga dapat dikatakan sebagai kemampuan yang ditunjukkan oleh peserta didik dalam pembelajaran (Dewi, 2018). Kompetensi merupakan sesuatu yang kompleks yang di dalamnya mengandung banyak aspek (ranah), yakni kompetensi sikap, pengetahuan, dan spiritual. Salah satu kompetensi pengetahuan yang terdapat di SD adalah kompetensi pengetahuan IPA. Kompetensi pengetahuan IPA adalah perubahan perilaku siswa yang mencerminkan kemampuan siswa terhadap penguasaan pembelajaran IPA dari segi pengetahuan setelah mengalami proses belajar. Untuk mengetahui informasi mengenai kemajuan peserta didik dalam upaya mencapai tujuan-tujuan belajarnya melalui pembelajaran terutama dalam muatan materi IPA dapat dilakukan proses penilaian terhadap kompetensi itu sendiri. Selain untuk memberikan penilaian evaluasi juga sebagai alat untuk memotivasi semangat belajar siswa.

Ilmu Pengetahuan Alam (IPA) merupakan salah satu bidang studi yang memiliki peranan penting dalam pembelajaran di Sekolah Dasar (SD). IPA merupakan ilmu pengetahuan yang mempelajari alam secara sistematis, bukan hanya konsep melainkan juga pada proses penemuan. Dengan kata lain, IPA merupakan ilmu pengetahuan yang objektif dan sistematik yang di dalamnya mempelajari tentang alam beserta isinya yang dapat diuji secara ilmiah. Dalam kehidupan sehari-hari sering ditemui bahwa siswa cenderung kurang untuk rasa ingin tahunya terhadap materi yang dipelajari sehingga menyebabkan rendahnya hasil belajar siswa itu sendiri (Lestari et al., 2017). Mengingat hal tersebut, IPA merupakan salah satu dari sekian ilmu pengetahuan yang menjadi dasar untuk muatan materi yang lebih kompleks (Rintayati, Putro, 2012).

Dalam menanamkan konsep muatan materi IPA dapat dilakukan dengan menyisipkan pembelajaran abad 21. Pembelajaran abad 21 dapat diartikan sebagai pembelajaran yang memberikan kecakapan abad 21 kepada peserta didik, yaitu 4C yang meliputi: (1) Communication (2) Collaboration, (3) Critical Thinking and Problem Solving, dan (4) Creative and Innovative (Zubaidah, 2016). Di era globalisasi ini, tentunya IPTEK sangat diperlukan guna menghadapi ancaman global dan juga pola pikir dari masyarakat akan berubah seiring berjalannya waktu. Maka dari itu diperlukannya keterampilan abad 21 dalam menghadapi ancaman tersebut (Dra. Ni Wayan Suniasih \& Drs. I Wayan Sujana, 2017).

Berdasarkan hasil observasi dan wawancara yang dilakukan bersama wali kelas IV di SD Negeri Gugus Jendral Sudirman Kecamatan Denpasar Selatan pada materi muatan IPA cenderung dibelajarkan guna menguasai konsep-konsep IPA sehingga belum optimalnya keterampilan proses yang diperoleh peserta didik. IPA memang membuat sebagian besar peserta didik merasa kesulitan karena materi yang cukup banyak (Widiantini et al., 2017). IPA seringkali dibelajarkan hanya bersifat hafalan tanpa adanya keterampilan proses yang diterima peserta didik (Juhji, 2016). Kondisi tersebut menyebabkan pembelajaran menjadi kurang bermakna bagi siswa, serta minat dan motivasi belajar siswa terhadap muatan materi IPA menjadi rendah. Siswa juga masih rendah dalam berfikir kritis sehingga kurang memperhatikan isu-isu sosial yang berada di masyarakat. Selain itu, kondisi pada saat siswa belajar juga cenderung kurang kondusif hal ini dapat menyebabkan pengetahuan yang diraih siswa kurang optimal (Hendrayana, 2017). Muatan materi IPA yang seharusnya menyenangkan dengan diikuti keterampilan proses malah menjadi membosankan dikarenakan masih bersifat menghafal konsep saja (Dwi Handayani et al., 2017). Selain itu literasi sains siswa juga cenderung masih rendah. Hal ini berbeda dengan pembelajaran IPA yang dilakukan melalui kegiatan praktik sehingga peserta didik tidak hanya melakukan olah pikir tetapi juga olah tangan (Ekasari et al., 2018). Kurangnya sikap sosial dan sikap peduli lingkungan pada siswa membuat proses belajar mengajar menjadi tersendat. Dan juga masih terdapat siswa yang kurang dalam menunjukkan sikap spiritualnya dalam berdoa sehari-hari. Melihat hal tersebut, IPA sangatlah kompleks dalam memberikan manfaat bagi kehidupan sehari-hari, mulai dari pengembangan potensi, sikap, keterampilan proses dll (Hendrayana, 2017). IPA juga tidak dapat 
terlepas dari kehidupan, karena merupakan salah satu dari sekian muatan pelajaran yang penting untuk dipelajari (Arisantiani et al., 2017). Terlebih lagi saat ini pemerintah mencanangkan agar optimalisasi peran guru dalam melaksanakan pembelajaran abad 21 dan HOTS. Pembelajaran pun perlu dilaksanakan secara kontekstual dengan menggunakan model, strategi, metode, dan teknik sesuai dengan karakteristik Kompetensi Dasar (KD) agar tujuan pembelajaran tercapai (Sugiyarti et al., 2018).

Untuk mewujudkan pembelajaran abad 21 dan HOTS, diperlukan model yang memiliki keterampilan proses yang baik dalam pembelajaran. Keterampilan proses dapat diartikan sebagai kemampuan dalam menyajikan pembelajaran sehingga mampu memberikan pengalaman belajar yang bermakna dan menyenangkan bagi siswa. Tentunya dalam mengemas suatu pembelajaran terdapat komponen-komponen penting yang mendukungnya, salah satunya ialah penggunaan model pembelajaran (Sari, 2016). Salah satu model pembelajaran yang dapat digunakan adalah model pembelajaran Sains Teknologi Masyarakat (STM).

Model Sains Teknologi Masyarakat (STM) merupakan model pembelajaran yang pada dasarnya membahas penerapan sains dan teknologi dalam konteks kehidupan manusia sehari-hari. Adapun tujuan dari model pembelajaran ini yaitu untuk membentuk individu yang memiliki literasi sains dan teknologi serta memiliki kepedulian terhadap masalah masyarakat dan lingkungannya. Dalam proses pembelajaran harus disiapkan sebaik mungkin agar siswa dapat menyentuh persoalan-persoalan yang ada di dalam kehidupan sehari-hari (Nurohman, 2006). Perlunya mempersiapkan isu-isu sesuai materi pembelajaran guna memancing motivasi siswa dalam membangun pengetahuannya sendiri (Suteja \& Wijayanti, 2017). Guna mempersiapkan diri dalam menghadapi kemajuan teknologi di era global saat ini, peserta didik juga sejak dini dapat merasakan manfaat dari penggunaan model STM (Pratiwi \& Nurhidayati, 2017). Dengan menerapkan model STM ini dapat meningkatkan hasil belajar peserta didik baik dari segi kognitif, psikomotor maupun afektifnya (Asikin et al., 2016). Dengan menggunakan model STM juga dapat lebih mandiri terlebih lagi dilihat dari muatan materi IPA yang tidak hanya mengandalkan konsep tetapi juga perlu adanya proses dalam pembelajaran (Putri et al., 2019).

Dalam penerapan model pembelajaran Sains Teknologi Masyarakat dapat dipadukan dengan konsep Tri Hita Karana karena dalam konsep Tri Hita Karana terdapat nilai - nilai yang dapat digunakan guna menunjang keberhasilan penerapan model pembelajaran Sains Teknologi Masyarakat tersebut. Tri Hita Karana sangat erat dalam kehidupan manusia khususnya masyarakat yang hidup di Bali (Dan et al., 2013). Sehingga penerapan model pembelajaran Sains Teknologi Masyarakat pada kompetensi pengetahuan IPA dalam pembelajaran sehari - hari disekolah dapat diterapkan dengan berbasis nilai Tri Hita Karana. Tri Hita Karana adalah tiga hal pokok yang menyebabkan kesejahteraan dan kemakmuran hidup manusia (Putera \& Supartha, 2014). Selain itu tiga unsur dalam Tri Hita Karana yakni meliputi : 1 . Hubungan Manusia dengan Tuhannya, 2. Hubungan Manusia dengan sesamanya, 3. Hubungan Manusia dengan lingkungannya (Wirawan, 2011).

Perpaduan tiga unsur itu secara harmonis sebagai landasana untuk terciptanya rasa hidup yang nyaman, tenteram, dan damai secara harafiah dan batiniah. Nilai-nilai yang terdapat dalam Tri Hita Karana merupakan nilai yang diambil dari ajaran-ajaran agama yang terdapat dalam kitab suci Veda dan masih menjadi acuan masyarakat dalam bertindak baik dipraktikkan dimasa kapanpun dan dimana pun. Nilai-nilai yang terkandung dalam Tri Hita Karana dapat menjadi acuan dalam meningkatkan sikap spiritual, sikap sosial dan juga sikap peduli lingkungan pada siswa. Nilai-nilai Tri Hita Karana juga dapat membawa siswa untuk hidup toleran terhadap segala ciptaan Tuhan (Paramajaya, 2018). Dengan diterapkannya nilai-nilai yang terkandung dalam tri hita karana, siswa menjadi lebih peduli terhadap rintangan yang dihadapinya yakni lingkungan (Ekasari et al., 2018).

Penelitian ini juga didukung oleh (Adnyani et al., 2017) pada siswa kelas V SD Negeri 1 Ubud. Berdasarkan hasil analisis yang dilakukan ditemukan bahwa siswa mendapatkan pengalaman secara langsung dalam suatu proses pembelajaran yang dapat membantu mereka dalam meningkatkan kompetensi secara optimal serta mengetahui cara belajar yang efektif dan meningkatkan pemahaman tentang muatan materi IPA. Selain itu juga terdapat hasil penelitian yang dilakukan oleh (I Wyn. Suarbawa, 2013) mendukung pelaksanaan model STM yang menyebutkan bahwa model STM mampu membuat siswa untuk belajar mandiri dan menjadi lebih aktif dan juga menambah wawasan dari siswa. Berdasarkan hal tersebut secara empiris perlu dibuktikan melalui penelitian dengan judul "Pengaruh Model Pembelajaran Sains Teknologi Masyarakat Berbasis Tri Hita Karana Terhadap Kompetensi Pengetahuan IPA Siswa Kelas IV Gugus Jendral Sudirman Kecamatan Denpasar Selatan Tahun Ajaran 2019/2020" 
Adapun tujuan penelitian ini adalah untuk mengetahui pengaruh yang signifikan model sains teknologi masyarakat berbasis tri hita karana terhadap kompetensi pengetahuan IPA siswa kelas IV.

\section{METODE}

Penelitian yang dilakukan ini bertempat di SDN Gugus Jenderal Sudirman Kecamatan Denpasar Selatan yang dilaksanakan pada bulan Februari sampai Maret, yaitu pada semester genap tahun ajaran 2019/2020. Jenis penelitian yang digunakan yaitu quasi eksperiment (Eksperimen Semu) dengan alasan keterbatasan kemampuan peneliti dalam mengamati perilaku siswa ketika diluar jam sekolah. Desain penelitian yang digunakan yaitu Nonequivalent Control Group Design yang melibatkan dua kelompok kelas, yaitu kelompok eksperimen dan kelompok kontrol.

Pelaksanaan penelitian ini terdiri dari tiga tahap yaitu, tahap persiapan, tahap pelaksanaan, dan tahap akhir eksperimen. Pada tahap persiapan eksperimen ini, kegiatan yang dilakukan, yakni; (1) menyusun Rencana Pelaksanaan Pembelajaran (RPP), (2) menyusun instrumen penelitian berupa tes kompetensi pengetahuan IPA, (3) mengkonsultasikan instrumen penelitian dengan guru kelas dan dosen pembimbing, (4) mengadakan validasi instrumen penelitian yaitu tes kompetensi pengetahuan IPA. Pada pada tahap pelaksanaan eksperimen kegiatan yang dilakukan yakni; (1) menentukan sampel penelitian berupa kelas dari populasi yang tersedia yaitu dengan teknik cluster random sampling, (2) dilakukan penyetaraan sampel dengan memberikan pre-test, (3) Setelah kedua kelas tersebut dinyatakan setara, dilakukan pengundian untuk kelas pertama yang muncul dijadikan kelompok eksperimen dan kelas kedua yang muncul dijadikan kelompok kontrol, (4) memberikan perlakuan pada kelompok eksperimen berupa model pembelajaran Sains Teknologi Masyarakat berbasis Tri Hita Karana. Pada tahap akhir eksperimen kegiatan yang dilakukan adalah memberikan post-test pada akhir penelitian untuk mengetahui kompetensi pengetahuan siswa pada masing-masing kelompok, menganalisis data hasil penelitian dan melakukan uji hipotesis.

Populasi dari penelitian ini adalah seluruh siswa kelas IV SD, yang terdiri dari 5 sekolah dengan jumlah kelas sebanyak 9 kelas. Jumlah populasi dari penelitian ini sebanyak 335 siswa. Dalam penelitian ini, sampel ditentukan dengan teknik cluster random sampling. Setelah mendapatkan sampel, kemudian diberikan pre test dengan tujuan untuk menyetarakan kedua kelompok sampel. Penyetaraan kelompok dilakukan dengan uji-t setelah melewati uji normalitas dan uji homogenitas. Jika data sudah dikatakan setara, maka dilakukan pengundian untuk menentukan kelas eksperimen dan kontrol. Hasil pengundian yaitu kelas IVB SDN 13 Sesetan sebagai kelas eksperimen dan kelas IVB SDN 6 Sesetan sebagai kelas kontrol.

Dalam penelitian ini terdapat dua kontrol validitas, yaitu validitas internal dan validitas eksternal. Validitas internal terdiri dari: 1) Sejarah, yang mungkin saja terjadi dikarenakan peristiwa yang terjadi ditengah-tengah pemberian tes kemampuan awal dan tes kemampuan akhir dan bukan dikarenakan eksperimen dari penelitian itu sendiri. Hal yang dapat dilakukan untuk menyiasati faktor tersebut adalah dengan cara mengharapkan kelompok kontrol memiliki pengalaman eksternal yang sama selama pelaksanaan perlakuan seperti pada kelompok eksperimen. 2) Kematangan, mungkin saja terjadi dari diri subjek yang diteliti yang terjadi diantara tes kemampuan awal dan tes kemampuan akhir dan bukan karena perlakuanUpaya yang dapat dilakukan adalah dengan menggunakan kelas kontrol yang mempunyai tingkat kematangan yang sama. 3) Regresi statistik diartikan sebagai kecondongan pada subkelompok subjek ketika diberikan tes ulang dengan variabel yang sama akan mempunyai rerata skor yang mendekati rerata skor kelompoknya. Upaya yang dapat dilakukan adalah dengan mengelak memilih subjek dengan skor terlalu tinggi. 4) Mortalitas merujuk pada efek yang disebabkan oleh perubahan komposisi kelompok dikarenakan adanya perpindahan subjek selama berlangsungnya perlakuan. Untuk menghindari adanya masalah yang diakibatkan oleh mortalitas eksperimental, maka perlu cara dengan membuat kelompok yang lebih besar dan mengambil langkah-langkah untuk menjamin representatif kelompok. Validitas eksternal berkaitan pada seberapa jauh hasil penelitian bisa di generalisasi kan di luar penelitian itu sendiri. Pengendalian terhadap hal tersebut dilakukan dengan membatasi penelitian pada kelas IV SDN Gugus Jenderal Sudirman Kecamatan Denpasar Selatan.

Data yang dikumpulkan pada penelitian ini yaitu data kompetensi pengetahuan IPA siswa. Metode yang digunakan adalah metode tes. Pada penelitian ini tes yang digunakan berupa tes obyektif dalam bentuk pilihan ganda biasa dengan 4 pilihan jawaban yang mengandung satu jawaban benar. Tes disusun melalui prosedur penyusunan kisi-kisi instrument, pembuatan butir-butir soal, uji coba instrumen, analisis hasil uji coba intrumen dengan pengujian intrumen dan penulisan akhir. 
Teknik analisis data yang digunakan adalah teknik analisis statistik deskriptif dan teknik analisis statistik inferensial. Kegiatan yang termasuk analisis statistik deskriptif diantaranya menentukan mean, standar deviasi, varians. Kegiatan yang termasuk analisis statistik inferensial adalah menentukan uji hipotesis dengan menggunakan uji-t (polled varians), sebelum melakukan uji hipotesis terlebih dahulu melewati uji prasyarat analisis yakni uji normalitas sebaran data dan uji homogenis varians.

\section{HASIL DAN PEMBAHASAN \\ Hasil}

Hasil penelitian ini memaparkan tentang mean, standar deviasi, varians, nilai tertinggi dan nilai terendah serta tabel distribusi frekuensi data bergolong. Tes kompetensi pengetahuan IPA yang digunakan dalam penelitian ini berjumlah 30 butir soal pilihan ganda biasa yang telah diuji validitas, reliabilitas, daya beda dan tingkat kesukaran. Post-tes diberikan setelah 6 kali treatment kelompok eksperimen maupun kelompok control. Hasil deskripsi data dapat dilihat pada tabel berikut.

\begin{tabular}{|c|c|c|}
\hline Hasil Analisis & Kelas Eksperimen & Kelas Kontrol \\
\hline Rata-rata (Mean) & 61.74 & 57.43 \\
\hline Standar Deviasi & 5.95 & 7.83 \\
\hline Varians & 35.41 & 61.25 \\
\hline Max & 73 & 73 \\
\hline Min & 50 & 40 \\
\hline
\end{tabular}

Berdasarkan data tersebut, dilanjutkan dengan menghitung rentang data, banyaknya kelas, Panjang kelas dan menghitung frekuensi (f) dan frekuensi relatif (f/n) yang langsung akan ditampilkan dalam bentuk tabel distribusi frekuensi sebagai berikut.

Tabel 2. Distribusi Frekuensi Data Bergolong Kompetensi Pengetahuan IPA Kelas Eksperimen

\begin{tabular}{|c|c|c|c|c|c|}
\hline & \multicolumn{3}{|c|}{ Interval } & \multirow{2}{*}{$\begin{array}{c}\text { Frekuensi } \\
3\end{array}$} & \multirow{2}{*}{$\begin{array}{c}\text { Frekuensi Relatif } \\
0.09\end{array}$} \\
\hline Kelas 1 & 49.5 & $\leq \mathrm{x}<$ & 53.5 & & \\
\hline Kelas 2 & 53.5 & $\leq \mathrm{x}<$ & 57.5 & 7 & 0.21 \\
\hline Kelas 3 & 57.5 & $\leq \mathrm{x}<$ & 61.5 & 10 & 0.29 \\
\hline Kelas 4 & 61.5 & $\leq x<$ & 65.5 & 3 & 0.09 \\
\hline Kelas 5 & 65.5 & $\leq \mathrm{x}<$ & 69.5 & 6 & 0.18 \\
\hline Kelas 6 & 69.5 & $\leq \mathrm{x} \leq$ & 73.5 & 5 & 0.15 \\
\hline \multicolumn{4}{|c|}{ Total } & 34 & 1.00 \\
\hline
\end{tabular}

Tabel 3. Distribusi Frekuensi Data Bergolong Kompetensi Pengetahuan IPA Kelas Kontrol

\begin{tabular}{|c|c|c|c|c|c|}
\hline \multicolumn{4}{|c|}{ Interval } & \multirow{2}{*}{$\begin{array}{c}\text { Frekuensi } \\
2\end{array}$} & \multirow{2}{*}{$\begin{array}{c}\text { Frekuensi Relatif } \\
0.05\end{array}$} \\
\hline Kelas 1 & 39.5 & $\leq \mathrm{x}<$ & 45.5 & & \\
\hline Kelas 2 & 45.5 & $\leq \mathrm{x}<$ & 51.5 & 8 & 0.22 \\
\hline Kelas 3 & 51.5 & $\leq \mathrm{x}<$ & 57.5 & 5 & 0.14 \\
\hline Kelas 4 & 57.5 & $\leq x<$ & 63.5 & 17 & 0.46 \\
\hline Kelas 5 & 63.5 & $\leq \mathrm{x}<$ & 69.5 & 3 & 0.08 \\
\hline Kelas 6 & 69.5 & $\leq x \leq$ & 75.5 & 2 & 0.05 \\
\hline \multicolumn{4}{|c|}{ Total } & 34 & 1.00 \\
\hline
\end{tabular}


Sebelum dilakukan uji hipotesis dengan menggunakan uji-t, terlebih dahulu dilakukan uji prasyarat yang meliputi uji normalitas data dan uji homogenitas varians. Untuk pengujian normalitas dilakukan dengan menggunakan analisis Chi-Square. Uji normalitas dilaksanakan guna mengetahui sebaran data dari skor kompetensi pengetahuan IPA siswa kelompok eksperimen maupun kontrol berdistribusi normal atau tidak. Berikut adalah hasil dari uji normalitas kelompok eksperimen dan kelompok kontrol yang disajikan dalam bentuk tabel.

Tabel 4. Hasil Uji Normalitas Kelompok Eksperimen dan Kelompok Kontrol

\begin{tabular}{ccccc}
\hline No & Sampel & $\mathbf{X}^{2}$ hit & $\mathbf{X}^{2}$ tabel & Keterangan \\
\hline 1 & Kelompok Eksperimen & 5,54 & 11,07 & Berdistribusi Normal \\
2 & Kelompok Kontrol & 5,89 & 11,07 & Berdistribusi Normal \\
\hline
\end{tabular}

Berdasarkan hasil analisis uji normalitas sebaran data, diperoleh harga $\mathrm{X}^{2} \mathrm{hit}$ yang diperoleh dari kelompok eksperimen $=5,54$, dan harga $\mathrm{X}^{2}$ hit yang diperoleh dari kelompok kontrol $=5,89$. Harga tersebut kemudian dibandingkan dengan harga X2tabel $=11,07$. Diperoleh data X2hit dari kedua kelompok kurang dari X2tabel $(5,54<11,07$ dan 5,89<11,07) maka Ho di terima atau Ha di tolak. Ini menandakan bahwa data kelompok eksperimen berdistribusi normal. Selanjutnya sebagai uji prasyarat analisis adalah dilakukan uji homogenitas varians. Uji homogenitas varians dilakukan terhadap data perolehan dari kedua kelompok dengan tujuan untuk mengetahui homogen atau tidaknya varians pada kedua kelompok.

Tabel 5. Uji Homogenitas Varians

\begin{tabular}{llccccc}
\hline No & \multicolumn{1}{c}{ Sampel } & Varians & $\mathbf{d k}$ & $\mathbf{F}_{\text {hitung }}$ & $\mathbf{F}_{\text {tabel }}$ & Kesimpulan \\
\hline 1 & Kelas Eksperimen & 35,41 & 34 & & & \\
2 & Kelas Kontrol & 61,25 & 37 & & 1,72 & Homogen \\
\hline
\end{tabular}

Berdasarkan hasil perhitungan diperoleh harga $\mathrm{F}_{\text {hitung }}=1,72$, angka itu selanjutnya dibandingkan dengan harga $F_{\text {tabel }}$ dengan taraf signifikansi $5 \%(\alpha=0,05)$ dengan dk untuk pembilang yaitu 37-1 = 36 dan dk untuk penyebut 34-1 = 33, sehingga dapat diperoleh $F_{\text {tabel }}=1,84$. Karena harga $F_{\text {hitung }}<F_{\text {tabel }}(1,72$ $<1,84$ ), ini berarti varians data penguasan kompetensi pengetahuan IPA antara kelompok eksperimen dan kelompok kontrol adalah sama atau homogen. Berdasarkan hasil uji prasyarat normalitas dan homogenitas varians dapat diketahui bahwa data yang diperoleh berdistribusi normal dan memiliki varians yang homogen. Selanjutnya dilakukan uji hipotesis dengan menggunakan analisis uji-t yang digunakan adalah rumus polled varians. Untuk hasil analisis uji hipotesis disajikan dalam tabel berikut.

Tabel 6. Uji Hipotesis

\begin{tabular}{ccccccccc}
\hline No & Sampel & $\mathbf{N}$ & $\mathbf{D k}$ & $\overline{\mathbf{X}}$ & $\mathbf{S}^{\mathbf{2}}$ & $\mathbf{t}_{\text {hitung }}$ & $\mathbf{t}_{\text {tabel }}$ & Simpulan \\
\hline 1 & Kelas Eksperimen & 34 & \multirow{2}{*}{69} & 61,74 & 35,41 & \multirow{2}{*}{2,391} & \multirow{2}{*}{1,994} & \multirow{2}{*}{$\mathrm{H}_{\mathrm{o}}$ ditolak } \\
2 & Kelas Kontrol & 37 & & 57,43 & 61,25 & & & \\
\hline
\end{tabular}

Berdasarkan hasil perhitungan dan tabel rekapitulasi hasil analisis uji-t, didapatkan thitung=2,391 pada taraf signifikansi $5 \%$ dengan $\mathrm{dk}=(34+37-2)=69$ didapatkan ttabel=1,994. Karena thitung > ttabel $(2,391>1,994)$ maka Ho ditolak atau Ha diterima sehingga terdapat perbedaan yang signifikan kompetensi pengetahuan IPA antara kelompok siswa yang dibelajarkan menggunakan model pembelajaran Sains Teknologi Masyarakat berbasis Tri Hita Karana dan kelompok siswa yang dibelajarkan mengunakan pembelajaran konvensional pada siswa kelas IV SD Gugus Jenderal Sudirman Kecamatan Denpasar Selatan Tahun Ajaran 2019/2020. 


\section{Pembahasan}

Siswa kelas IVB SDN 13 Sesetan merupakan kelas yang ditetapkan sebagai kelas eksperimen. Siswa kelas eksperimen terdiri dari 34 orang siswa. Sedangkan kelas IVB SDN 6 Sesetan merupakan kelas yang ditetapkan sebagai kelas kontrol. Siswa kelas kontrol terdiri dari 37 orang siswa. Siswa di kelas eksperimen diberikan perlakuan berupa model pembelajaran Sains Teknologi Masyarakat berbasis Tri Hita Karana, sedangkan siswa di kelas kontrol tidak diberikan perlakuan berupa model pembelajaran Sains Teknologi Masyarakat berbasis Tri Hita Karana. Sebelum diberikan perlakuan, kedua kelompok ditemukan setara secara akademik berdasarkan hasil analisis uji kesetaraan menggunakan uji-t, hal ini menunjukkan bahwa setelah diberikan perlakuan, perbedaan yang ditemukan setelahnya adalah pengaruh daripada perlakuan yang berbeda di setiap kelompok. Perlakuan terhadap kedua kelompok diberikan masing-masing sebanyak 6 kali yang kemudian setelah perlakuan akan diberikan post tes.

Tes yang digunakan dalam pemberian post-tes adalah tes kompetensi pengetahuan IPA berbentuk pilihan ganda biasa sebanyak 30 butir soal. Data yang diperoleh dari hasil rata-rata kompetensi pengetahuan IPA siswa kelompok eksperimen lebih besar dari rata-rata kompetensi pengetahuan IPA siswa kelompok kontrol yakni $61,74>57,43$, hal ini menandakan bahwa ditemukan pengaruh daripada model Sains Teknologi Masyarakat berbasis tri hita karana terhadap kompetensi pengetahuan IPA siswa. Selain itu, berdasarkan dari perolehan analisis uji-t pada $\mathrm{dk}=69$ dan pada derajat signifikansi $5 \%$ didapatkan harga thitung > ttabel $(2,391>1,994)$ sehingga dapat disimpulkan bahwa ditemukan perbedaan yang signifikan kompetensi pengetahuan IPA antara kelompok siswa yang dibelajarkan mempergunakan model Sains Teknologi Masyarakat berbasis tri hita karana dan kelompok siswa yang tidak dibelajarkan mempergunakan model Sains Teknologi Masyarakat berbasis tri hita karana.

Bersumber pada hasil analisis data tersebut, perbedaan yang ditemukan ini ditimbulkan oleh adanya penerapan model Sains Teknologi Masyarakat berbasis Tri Hita Karana pada kelas eksperimen sedangkan pada kelas kontrol tidak diberikan perlakuan berupa penerapan model yang sama. Model Sains Teknologi Masyarakat berbasis Tri Hita Karana mengajak siswa untuk aktif serta dapat memaknai proses belajar mengajar sehingga dapat diterapkan dalam kehidupan sehari-hari siswa. Siswa juga dapat meningkatkan sikap spiritual, sikap sosial dan juga sikap peduli lingkungan pada siswa seperti nilai-nilai yang terkandung dalam Tri Hita Karana. Dengan menggunakan model STM berbasis Tri Hita Karana siswa dapat membentuk pengetahuan siswa untuk mempunyai literasi sains dan melek teknologi serta mempunyai kepedulian terhadap masalah yang dihadapi masyarakat dan lingkungannya.

Model STM mengaitkan antara sains dan teknologi serta manfaatnya terhadap masyarakat (Poedjiadi, 2019). Kompetensi pengetahuan IPA menjadi salah satu hal penting yang berkenaan dengan pengetahuan, keterampilan, dan sikap dalam melaksanakan tugas khususnya dalam ranah kognitif muatan IPA. Berdasarkan pentingnya kompetensi pengetahuan IPA tersebut maka diujicobakan suatu model pembelajaran yakni model Sains Teknologi Masyarakat. Model ini juga adalah usaha dalam membelajarkan sains dan teknologi kedalam kehidupan sehari - hari, yang berfocus terhadap masalah yang terjadi dimasyarakat. Selain itu siswa juga dapat menjaga keharmonisan hubungan yang mengacu pada nilai-nilai yang terkandung dalam Tri Hita Karana. Dengan ini maka siswa akan lebih termotivasi dalam belajar dan juga dapat meningkatkan sikap peduli lingkungan serta peduli sosial peserta didik (Desfandi, 2015). Dengan menerapkan nilai-nilai Tri Hita Karana akan memudahkan dalam menyampaikan materi pelajaran terutama untuk muatan materi IPA (Widiartini et al., 2019). Model tersebut juga dapat meningkatkan kemampuan berpikir kritis siswa sehingga mengajak siswa untuk siap menghadapi perkembangan global yang akan datang (Junanto \& Afriani, 2016).

Penelitian ini juga didukung oleh (Adnyani et al., 2017) pada siswa kelas V SD Negeri 1 Ubud. Berdasarkan hasil analisis yang dilakukan ditemukan bahwa siswa mendapatkan pengalaman secara langsung dalam suatu proses pembelajaran yang dapat membantu mereka dalam meningkatkan kompetensi secara optimal serta mengetahui cara belajar yang efektif dan meningkatkan pemahaman tentang muatan materi IPA.

\section{SIMPULAN DAN SARAN}

Berdasarkan hasil penelitian dan pembahasan maka dapat dinyatakan bahwa hasil penelitian sebagai berikut: (1) Data yang diperoleh dari hasil rata-rata kompetensi pengetahuan IPA siswa kelompok eksperimen lebih besar dari rata-rata kompetensi pengetahuan IPA siswa kelompok kontrol 
yakni $61,74>57,43$, hal ini menandakan bahwa ditemukan pengaruh daripada model Sains Teknologi Masyarakat berbasis tri hita karana terhadap kompetensi pengetahuan IPA siswa. (2) Selain itu, berdasarkan dari perolehan analisis uji-t pada $\mathrm{dk}=69$ dan pada derajat signifikansi 5\% didapatkan harga thitung $>$ ttabel $(2,391>1,994)$ sehingga dapat disimpulkan bahwa ditemukan perbedaan yang signifikan kompetensi pengetahuan IPA antara kelompok siswa yang dibelajarkan mempergunakan model Sains Teknologi Masyarakat berbasis tri hita karana dan kelompok siswa yang tidak dibelajarkan mempergunakan model Sains Teknologi Masyarakat berbasis tri hita karana.

Jadi, dapat disimpulkan model Sains Teknologi Masyarakat berbasis tri hita karana berpengaruh terhadap kompetensi pengetahuan IPA siswa kelas IV SD.

Adapun saran kepada phak-pihak terkait yaitu (1) Kepada guru, disarankan untuk bisa menggunakan model Sains Teknologi Masyarakat berbasis Tri Hita Karana sebagai salah satu alternatif dalam pembelajaran sehingga siswa dapat lebih aktif dan memperoleh pengalaman belajar bagi peserta didik, (2) Kepada kepala sekolah, disarankan untuk dapat menggunakan hasil penelitian ini sebagai referensi kepada guru di sekolah lainnya sebagai model pembelajaran inovatif untuk pembelajaran yang efektif dan efisien serta mampu meningkatkan mutu pendidikan, (3) Kepada peneliti lain, disarankan untuk menggunakan hasil penelitian ini sebagai referensi dan sumber informasi dalam melakukan penelitian pengembangan mengenai model pembelajaran tersebut diatas sehingga dapat memperoleh hasil yang lebih baik kedepannya.

\section{DAFTAR PUSTAKA}

Adnyani, A. M., Ardana, I. K., \& Putra, I. K. A. (2017). Pengaruh Pendekatan Saintifik Berbantuan Model Sains Teknologi Masyarakat Terhadap Kompetensi Pengetahuan IPA Siswa Kelas V. Journal of Education Technology. https://doi.org/10.23887/jet.v1i2.11746

Arisantiani, N. K., Putra, M., \& Ganing, N. N. (2017). Pengaruh Model Pembelajaran Childrens Learning In Science (CLIS) Berbantuan Media Lingkungan Terhadap Kompetensi Pengetahuan IPA. Journal of Education Technology. https://doi.org/10.23887/jet.v1i2.11774

Asikin, N., Irawati, mimien henie, \& Syamsuri, I. (2016). Pembelajaran Biologi Berpendekatan Saintifik Model Sains Teknologi. Pedagogi Hayati.

Dan, K., Sains, S., \& Smp, S. (2013). Pengaruh Model Pembelajaran Sains Teknologi Masyarakat ......... . Jurnal Ilmiah PROGRESSIF.

Desfandi, M. (2015). Mewujudkan masyarakat berkarakter peduli lingkungan melalui program Adiwiyata. Sosio Didaktika: Social Science Education Journal. https://doi.org/10.15408/sd.v2i1.1661

Dewi, N. P. S. (2018). Pengaruh Model Pembelajaran Learning Cycle 5e Berbantuan Media Lingkungan Terhadap Kompetensi Pengetahuan Ipa. Jurnal Penelitian Dan Pengembangan Pendidikan. https://doi.org/10.23887/jppp.v2i2.15389

Dra. Ni Wayan Suniasih, S., \& Drs. I Wayan Sujana, S. (2017). Pengaruh Model Pembelajaran Talking Chips Berbasis Tri Hita Karana Terhadap Kompetensi Pengetahuan Ips. MIMBAR PGSD Undiksha, 5(2). https://doi.org/10.23887/jjpgsd.v5i2.10659

Dwi Handayani, N. M., Ganing, N. N., \& Suniasih, N. W. (2017). Model Pembelajaran Picture and Picture Berbantuan Media Audio-Visual Terhadap Kompetensi Pengetahuan IPA. Journal of Education Technology. https://doi.org/10.23887/jet.v1i3.12502

Ekasari, N. L. P., Smara Putra, D. K. N., \& Surya Abadi, I. B. G. (2018). Pengaruh Model Pembelajaran Generatif Berbasis Lingkungan Terhadap Kompetensi Pengetahuan IPA. Jurnal Ilmiah Sekolah Dasar. https://doi.org/10.23887/jisd.v2i2.15495

Hasjunianti. (2006). Penerapan Pendekatan Sains Teknologi Masyarakat ( STM ) untuk Meningkatkan Pemahaman Tentang Energi dan Penggunaannya Pada Siswa Kelas IV SDN 024 Salukaili. Jurnal Kreatif Tadulako Online.

Hendrayana, S. (2017). Meningkatkan Keterampilan Berpikir Rasional Siswa Melalui Model Sains Teknologi Masyarakat pada Konsep Sumber Daya Alam. Pendas : Jurnal Ilmiah Pendidikan Dasar. https://doi.org/10.23969/jp.v2i1.471

I Wyn. Suarbawa, N. W. A. I. D. P. R. R. (2013). Pengaruh Model Pembelajaran Sains Teknologi Masyarakat (STM) Terhadap Hasil Belajar IPS Siswa Kelas IV SD Gugus I Kecamatan Buleleng. Mimbar PGSD Undiksha. https://doi.org/10.23887/JJPGSD.V1I1.1263

Juhji. (2016). Model Pembelajaran Sains Teknologi Masyarakat dalam Pembelajaran IPA. Primary. 
Junanto, T., \& Afriani, R. (2016). Implementasi Digital-Age Literacy Dalam Pendidikan Abad 21 Di Indonesia. Prosiding Seminar Nasional Pendidikan Sains.

Lestari, H., Ayub, S., \& Hikmawati, H. (2017). Penerapan Model Pembelajaran Sains Teknologi Masyarakat (STM) untuk Meningkatkan Hasil Belajar Fisika Siswa Kelas VIII SMPN 3 Mataram. Jurnal Pendidikan Fisika Dan Teknologi. https://doi.org/10.29303/jpft.v2i3.297

Nurohman, S. (2006). Hal Ini Menyebabkan Pembelajaran Menjadi Tidak Bermakna, Peserta Didik Tercerabut Dari Kehidupan Nyata, Dan Pada Akhirhya Pendidikan Tidak Mampu Memberikan Bekal. Penerapan Pendekatan Sains-Teknologi-Masyarakat (STM) dalam Pembelajaran IPA Sebagai Upaya Peningkatan Life Skills Peserta Didik.

Paramajaya, I. P. G. (2018). Implementasi Konsep Tri Hita Karana Dalam Perspektif Kehidupan Global : Berpikir Global Berperilaku Lokal. Purwadita.

Poedjiadi, Anna. 2019. Sains Teknologi Masyarakat, Model Pembelajaran Kontekstual Bermuatan Nilai. Bandung: PT. Remaja Rosdakarya.

Pratiwi, U., \& Nurhidayati, N. (2017). Penerapan Sains Teknologi Masyarakat (STM) untuk Peningkatkan Kemampuan Pedagogik Guru dan Calon Guru Paud Kec. Panjer Kab. Kebumen. Journal of Dedicators Community. https://doi.org/10.34001/jdc.v1i1.441

Putera, I., \& Supartha, W. (2014). Penerapan Konsep Tri Hita Karana dalam Hubungannya dengan Budaya Organisasi di Rektorat UNUD. E-Jurnal Manajemen Universitas Udayana.

Putri, N. M. C. N. M., Ardana, I. K., \& Agustika, G. N. S. (2019). Pengaruh Model Discovery Learning Berbantuan Lingkungan Terhadap Kompetensi Pengetahuan IPA Siswa Kelas V. Mimbar PGSD.

Riastuti, R. D. (2015). Penerapan Pendekatan Sains Teknologi Lingkungan Masyarakat untuk Meningkatkan Aktivitas dan Hasil Belajar Biologi di SMAN 1 Kota Padang. Jurnal Bioedukatika. https://doi.org/10.26555/bioedukatika.v3i2.4152

Rintayati, Putro, P. (2012). Meningkatkan Aktivitas Belajar (Active Learning) Siswa Berkarakter Cerdas Dengan Pendekatan Sains Teknologi (Stm). Jurnal Didaktika Dwija Indria.

Sugiyarti, L., Arif, A., \& Mursalin. (2018). Pembelajaran Abad 21 di SD. Prosiding Seminar Dan Diskusi Nasional Pendidikan Dasar.

Sujana, A. 2014. Pendidikan IPA Teori dan Praktik. Bandung: Rizqy Press

Suteja, I. P. dan, \& Wijayanti, A. (2017). Pendekatan sains teknologi masyarakat terhadap hasil belajar ipa siswa kelas viii. Jurnal Ilmiah Pendidikan IPA.

Widiantini, N. N. A. S., Putra, M., \& Wiarta, I. W. (2017). Model Pembelajaran Sets (Science, Environment, Technology, Society) Berbantuan Virtual Lab Berpengaruh Terhadap Kompetensi Pengetahuan IPA. Journal of Education Technology. https://doi.org/10.23887/jet.v1i2.11776

Widiartini, P. D. O., Made Putra, M. P., \& Manuaba, I. B. S. (2019). Pengaruh Model Pembelajaran Group Investigation Berbasis Tri Hita Karana Terhadap Kompetensi Pengetahuan IPA. Jurnal Ilmiah Sekolah Dasar. https://doi.org/10.23887/jisd.v3i3.19476

Wirawan, I Made Adi. 2011. Tri Hita Karana Kajian Teologi, Sosiologi dan Ekologi Menurut Veda. Jakarta: Prenadamedia Group

Zubaidah, S. (2016). Keterampilan Abad Ke-21: Keterampilan Yang Diajarkan Melalui Pembelajaran. Seminar Nasional Pendidikan. https://doi.org/10.1021/acs.langmuir.6b02842 